\title{
Effect of Growth Stage-Based Irrigation Schedules on Biomass Accumulation and Resource Use Efficiency of Wheat Cultivars
}

\author{
Muhammad Mubeen ${ }^{1 *}$, Ashfaq Ahmad ${ }^{1}$, Aftab Wajid ${ }^{1}$, Tasneem Khaliq ${ }^{1}$, Syeda Refat Sultana ${ }^{1}$, \\ Shahid Hussain ${ }^{1}$, Amjed $\mathrm{Ali}^{2}$, Hakoomat $\mathrm{Ali}^{3}$, Wajid Nasim ${ }^{4}$ \\ ${ }^{1}$ Agro-Climatology Laboratory, Department of Agronomy, University of Agriculture, Faisalabad, Pakistan; ${ }^{2}$ University College of \\ Agriculture, University of Sargodha, Sargodha, Pakistan; ${ }^{3}$ Department of Agronomy, Faculty of Agricultural Sciences and Technol- \\ ogy, Bahauddin Zakariya University, Multan, Pakistan; ${ }^{4}$ Department of Environmental Sciences, COMSATS Institute of Information \\ Technology, Vehari, Pakistan. \\ Email: *mubeenagri@gmail.com
}

Received May $5^{\text {th }}, 2013$; revised June $7^{\text {th }}, 2013$; accepted June $25^{\text {th }}, 2013$

Copyright (C) 2013 Muhammad Mubeen et al. This is an open access article distributed under the Creative Commons Attribution License, which permits unrestricted use, distribution, and reproduction in any medium, provided the original work is properly cited.

\begin{abstract}
Climate and weather conditions greatly affect the performance of new wheat cultivars for yield and resource use efficiency. In order to know the effect of irrigation schedules based on growth stage (the most vital criterion in the region) on growth, yield and radiation use efficiency of wheat cultivars in Faisalabad conditions, a study was planned at Agronomic Research Area, University of Agriculture, Faisalabad during 2009-2010. Split plot design with irrigation levels in main plots and cultivars in sub-plots was implied. Irrigation levels were: IT = irrigation at tillering stage, ITS = irrigation at tillering and stem elongation stage, ISB = irrigation at stem elongation and booting stage and ITSBG = irrigation at tillering, stem elongation, booting and grain filling stage. Cultivars selected were: Faisalabad-2008, Lasani-2008, Miraj-2008, Shafaq-2006 and Chakwal-97. Irrigation treatment ITSBG gave higher grain yield $\left(4.23 \mathrm{t} \cdot \mathrm{ha}^{-1}\right)$ followed by ISB $\left(3.60 \mathrm{t} \cdot \mathrm{ha}^{-1}\right)$, however ITSBG was statistically similar to ISB in radiation use efficiency (RUE) for grain yield $\left(\mathrm{RUE}_{\mathrm{GY}}\right)$. Similarly the two treatments were statistically at par in maximum leaf area index, total dry matter (TDM) accumulation, cumulative photosynthetically active radiation (PAR), and RUE $\mathrm{TDM}_{\text {. }}$. Hence where less numbers of irrigations are available, irrigation at stem elongation and booting stage is suitable for achieving economic yield. Lasani-2008 produced maximum grain yield $\left(4.37 \mathrm{t} \cdot \mathrm{ha}^{-1}\right)$ compared to other cultivars but it was statistically at par with Shafaq-2006 in plant height, TDM production and $\mathrm{RUE}_{\mathrm{TDM}}$. Depending on the availability, the two cultivars may be chosen under irrigated conditions of Faisalabad.
\end{abstract}

Keywords: Triticum aestivum L.; Irrigation; Photosynthetically Active Radiation (PAR); Radiation Use Efficiency (RUE); Total Dry Matter (TDM)

\section{Introduction}

In spite of higher yield potential, average grain yield of wheat in Pakistan is much less than most countries of the world. The yield of wheat depends on many factors, the cultivars and irrigation being the most important ones. Cereal cultivators are encountered with a greater choice of new cultivars both from the public and private sectors, often with little appropriate information available on their performance in the local environment. Wheat cropping areas of Punjab are usually less productive due to improper selection of variety [1]. Climate and weather

\footnotetext{
"Corresponding author.
}

conditions greatly affect the performance of new wheat cultivars both for yield and resource use efficiency [2]. Similarly different varieties of wheat respond differently to irrigation treatments. The span of dry period cannot be forecast under arid and semi-arid conditions which mostly prevail in Pakistan and satisfactory grain yields are dependent upon the crop cultivar for its ability to tolerate water stress [3].

Irrigation water is vital for cell turgidity which is associated with photosynthesis, growth of tissues and plant organs [4]. The response of plants to varying degrees of water levels has been a subject of extensive study and evaluation $[5,6]$. Earlier research showed that irrigation 
consistently increased wheat yield in Pakistan [7-11]. At tillering, anthesis and grain formation stages availability of water is important for better performance of the crop. At anthesis stress of water reduces pollination and thus less number of grains spike-1 which ultimately result in low grain yield [12] and irrigation at crown root initiation, tillering, jointing, flowering and milking stages influence most the value of growth parameters [13].

The effect of wheat varieties alone and in interaction with deficit irrigation on photosynthetically active radiation utilization (PAR) has been previously tested in a number of studies. Three wheat cultivars (Uqab-2000, AS-2002, and Inqlab-91) differed significantly from one another in leaf area index, leaf area duration, net assimilation rate and radiation use efficiency [14]. Similarly, there were significant differences among cultivars in radiation use efficiency for total dry matter. AS-2002 showed maximum radiation use efficiency $\left(2.66 \mathrm{~g} \cdot \mathrm{MJ}^{-1}\right)$ while minimum radiation use efficiency $\left(2.16 \mathrm{~g} \cdot \mathrm{MJ}^{-1}\right)$ was observed in Iqbal-2000 [15]. The wheat cultivar Uqab-2000 performed very well under Faisalabad conditions. In an experiment conducted by [16], it was found that whether irrigated at jointing stage or not, the difference between Jimai-20 and Lainong-0153 in the amount of intercepted photosynthetically active radiation was non-significant. During the late growing season of winter wheat, irrespective of the irrigation levels, the radiation use efficiency and GY of Jimai-20 were significantly higher than those of Lainong-0153.

Intercepted PAR is the main factor determining both spike and crop growth period, and grain number $\mathrm{m}^{-2}$ is linearly related to the accumulated intercepted PAR during this period [17]. Measurements of after-anthesis radiation use efficiency (RUE) not only showed that it was reduced in all cultivars, but also confirmed that during grain filling period the sink size may exert a great effect on post-anthesis RUE through reducing the leaf photosynthetic rates [18].

This paper examines the effect of different irrigation schedules based on growth stage (the most vital criterion in the region) on the growth, yield and radiation use efficiency of different wheat varieties under semiarid conditions of Faisalabad.

\section{Materials and Methods}

\subsection{Experimental Site}

The study was conducted in rabi (winter) season 20092010 at Agronomic Research Area, University of Agriculture, Faisalabad (Latitude $31.25^{\circ} \mathrm{N}$, Longitude $73.06^{\circ} \mathrm{E}$ and $184.4 \mathrm{~m}$ a.s.1.). The soil of the plot is a sandy clay loam. The concentration of organic matter of the plot is low $(0.78 \%)$ which is peculiar of the area. The analysis of soil before sowing showed that level of rapidly available phosphorous was $6.85 \mathrm{mg} / \mathrm{kg}$, potassium was 189 $\mathrm{mg} / \mathrm{kg}$ (an appreciable amount which is due to canal irrigation) and nitrogen was $0.071 \%$. The bulk density, field moisture capacity and wilting points were $1.4 \mathrm{~g} \cdot \mathrm{cm}^{-3}$, $20.2 \%$ and $11.6 \%$, respectively. Agriculture in this region is intensified by a double cropping system of winter wheat and autumn maize or rice with high-yielding cultivars and high fertilizer and water inputs.

\subsection{Weather Data}

All weather data for the whole crop growth period were collected from the meteorological observatory $100 \mathrm{~m}$ away from the experimental site. Table 1 shows the mean monthly data of different climatic factors. The average temperature ranged from $11.1^{\circ} \mathrm{C}$ to $29.9^{\circ} \mathrm{C}$ during the crop growth season. April was the warmest month having mean maximum temperature $29.9^{\circ} \mathrm{C}$ while January was the coldest month with mean minimum temperature of $11.1^{\circ} \mathrm{C}$. Total rainfall during the season was $23.5 \mathrm{~mm}$ and maximum rainfall occurred in the month of February $(11.9 \mathrm{~mm})$.

\subsection{Experimental Design}

The experiment was conducted in triplicate using a split plot design. Previous studies and recommendations of

Table 1. Summary of meteorological data during the crop growth season November 2009-April 2010.

\begin{tabular}{|c|c|c|c|c|c|c|}
\hline Month & Temperature Mean $\left({ }^{\circ} \mathrm{C}\right)$ & Rainfall Total (mm) & R. H Mean (\%) & Sun shine (hours) & Mean ET (mm) & Wind Speed $(\mathrm{km} / \mathrm{h})$ \\
\hline November & 18.2 & 0.7 & 64.7 & 6.3 & 1.3 & 3.3 \\
\hline December & 14.5 & 0 & 64.4 & 6.6 & 1.2 & 2.8 \\
\hline January & 11.1 & 0.8 & 82.3 & 4.1 & 0.8 & 4.4 \\
\hline February & 15.7 & 11.9 & 62.7 & 6.6 & 2.5 & 5.0 \\
\hline March & 23.5 & 8.8 & 57.5 & 8.7 & 3.4 & 3.6 \\
\hline April & 29.9 & 1.3 & 36.8 & 9.0 & 6.0 & 5.8 \\
\hline Total & - & 23.5 & - & - & - & - \\
\hline
\end{tabular}


Department of Agriculture [19-21] recommend that four stages (tillering, stem elongation, booting and grain filling) are critical for wheat at which water application is required the most, so if less number of irrigations are available which irrigation should be skipped for a particular cultivar is a matter of consideration. Hence treatments of water application and skipping irrigations at these growth stages were planned. Split plot design with irrigation levels in main plots and cultivars in sub-plots was implied. More detailed information of the treatments is shown in Table 2. The canal water was supplied to the plots using improved earthen watercourse and hence cut throat flume was used to measure the amount of water applied. Between two irrigation plots, there was a $1.5 \mathrm{~m}$ wide zone (kept as buffer plot) to minimize the effects of two contiguous plots.

\subsection{Crop Husbandry}

"Rouni" (soaking) irrigation was applied to the field twelve days before sowing to bring the soil moisture level at field capacity. Deep ploughing was done followed by two cultivations and planking to prepare the seedbed. The crop was sown with the help of single row hand drill. Half of nitrogen and whole of the phosphorous and potash were applied at sowing as a basal dose whereas remaining nitrogen was applied at first irrigation by broadcast method. The rate of the three nutrients is given in Table 2.

\subsection{Observations}

After establishment five plants were tagged in each plot to study growth stages of tillering, stem elongation, anthesis and maturity. A $25 \mathrm{~cm}$ long row areawas harvested at 15 days interval. A sub sample of $10 \mathrm{~g}$ was used for measuring leaf area by leaf area meter (CID-202). Appropriate sub samples of different plant fractions (leaf, stem and ear) were dried in an oven at $80^{\circ} \mathrm{C}$ for $72 \mathrm{~h}$. Leaf area index (LAI) was determined as ratio of leaf area to land area. The fraction of intercepted radiation (Fi) was calculated from measurements of LAI using the exponential equation as suggested by [22].

$$
\mathrm{Fi}=1-\exp (-\mathrm{k} \times \mathrm{LAI})
$$

where $\mathrm{k}$ is a light transmission co-efficient for total solar radiation and a $\mathrm{k}$ value of 0.45 was used for wheat as described by [23]. Photosynthetically active radiation (PAR) was taken equal to half (0.5) of total incident radiation ( $\mathrm{Si}$ ) as suggested by [24]. Multiplying these totals by appropriate estimates of Fi gave the amount of intercepted radiation $\left(\sum \mathrm{Sa}\right)$.

$$
\mathrm{Sa}=\mathrm{Fi} \times \mathrm{Si}
$$

Radiation use efficiency for TDM (RUE $\mathrm{RDM}_{\mathrm{TDM}}$ ) and grain yield $\left(\mathrm{RUE}_{\mathrm{GY}}\right)$ was calculated as the ratio of total biomass and grain yield to cumulative intercepted PAR $\left(\sum \mathrm{Sa}\right)$.

At maturity, an area of $6 \mathrm{~m}^{2}$ was harvested manually from each plot to determine the total biomass and grain yield which were then converted to tons $\mathrm{ha}^{-1}$. Analysis of variance technique was employed to analyze the data. Differences among the treatment means were compared using least significant difference (LSD) at $5 \%$ probability level [25].

\section{Results and Discussion}

\subsection{Plant Height}

Table 3 showed that application of irrigation had significant effect on plant height. Maximum plant height of

\begin{tabular}{|c|c|c|c|c|c|c|c|c|}
\hline \multicolumn{9}{|c|}{ Treatments } \\
\hline \multicolumn{6}{|c|}{ Main plot $=$ Irrigation } & \multicolumn{3}{|c|}{ Sub plot $=$ cultivars } \\
\hline Level & \multicolumn{5}{|c|}{ Description } & Level & \multicolumn{2}{|c|}{ Description } \\
\hline IT & \multicolumn{5}{|c|}{ Irrigation at tillering stage } & $\mathrm{V}_{1}$ & \multicolumn{2}{|c|}{ Faisalabad-2008 } \\
\hline ITS & \multicolumn{5}{|c|}{ Irrigation at tillering and stem elongation stage } & $\mathrm{V}_{2}$ & \multicolumn{2}{|c|}{ Lasani-2008 } \\
\hline ISB & \multicolumn{5}{|c|}{ Irrigation at stem elongation and booting stage } & $\mathrm{V}_{3}$ & \multicolumn{2}{|c|}{ Miraj-2008 } \\
\hline \multirow[t]{2}{*}{ ITSBG } & \multicolumn{5}{|c|}{ Irrigation at tillering, stem elongation, booting and grain filling stages } & $\mathrm{V}_{4}$ & \multirow{2}{*}{\multicolumn{2}{|c|}{$\begin{array}{l}\text { Shafaq-2006 } \\
\text { Chakwal-97 }\end{array}$}} \\
\hline & & & & & & $\mathrm{V}_{5}$ & & \\
\hline \multicolumn{9}{|c|}{ Planting information } \\
\hline Sowing date & Design & Replication & Net plot size & $\mathrm{R} \times \mathrm{R}$ & $\begin{array}{l}\text { Seed rate } \\
\left(\mathrm{kg} \cdot \mathrm{ha}^{-1}\right)\end{array}$ & $\mathrm{N}\left(\mathrm{kg} \cdot \mathrm{ha}^{-1}\right)$ & $\mathrm{P}\left(\mathrm{kg} \cdot \mathrm{ha}^{-1}\right)$ & $\mathrm{K}\left(\mathrm{kg} \cdot \mathrm{ha}^{-1}\right)$ \\
\hline November 12 & Split plot & 3 & $2.4 \mathrm{~m} \times 5.0 \mathrm{~m}$ & $30 \mathrm{~cm}$ & 100 & 110 & 85 & 65 \\
\hline
\end{tabular}

Table 2. Design specifications and agronomic practices. 
Table 3. Effect of cultivars and irrigation on yield and radiation-associated traits of wheat.

\begin{tabular}{|c|c|c|c|c|c|c|c|}
\hline & Treatments & Plant Height $(\mathrm{cm})$ & Grain Yield $\left(\mathrm{t} \cdot \mathrm{ha}^{-1}\right)$ & HI (\%) & $\operatorname{PAR}\left(\mathrm{MJ} \cdot \mathrm{m}^{-2}\right)$ & $\operatorname{RUE}_{\mathrm{TDM}}\left(\mathrm{g} \cdot \mathrm{MJ}^{-1}\right)$ & $\operatorname{RUE}_{\mathrm{GY}}\left(\mathrm{g} \cdot \mathrm{MJ}^{-1}\right)$ \\
\hline \multirow{6}{*}{ Irrigation } & $\mathrm{IT}^{\mathrm{a}}$ & $88.07 \mathrm{~b}$ & $3.01 \mathrm{c}$ & $31.36 \mathrm{c}$ & $337.66 \mathrm{c}$ & $2.48 \mathrm{~b}$ & $0.82 \mathrm{~b}$ \\
\hline & ITS & $95.88 \mathrm{a}$ & $3.53 \mathrm{~b}$ & $34.81 \mathrm{ab}$ & $364.14 \mathrm{~b}$ & $2.76 \mathrm{ab}$ & $0.90 \mathrm{~b}$ \\
\hline & ISB & $89.91 \mathrm{~b}$ & $3.61 \mathrm{~b}$ & $33.29 \mathrm{bc}$ & $391.49 \mathrm{a}$ & $2.77 \mathrm{ab}$ & $0.98 \mathrm{ab}$ \\
\hline & ITSBG & $90.79 \mathrm{~b}$ & $4.23 \mathrm{a}$ & $36.93 \mathrm{a}$ & $413.60 \mathrm{a}$ & $3.07 \mathrm{a}$ & $1.07 \mathrm{a}$ \\
\hline & $S \bar{x}$ & 1.08 & 0.14 & 0.75 & 6.86 & 0.13 & 0.05 \\
\hline & LSD & 3.74 & 0.48 & 2.59 & 23.76 & 0.32 & 0.16 \\
\hline \multirow{7}{*}{ Cultivars } & $\mathrm{V}_{1}$ & $93.03 \mathrm{a}$ & $3.51 \mathrm{c}$ & $33.67 \mathrm{c}$ & $376.88 \mathrm{bc}$ & $2.77 \mathrm{ab}$ & $0.92 \mathrm{bc}$ \\
\hline & $\mathrm{V}_{2}$ & $88.53 \mathrm{~b}$ & $4.37 \mathrm{a}$ & $39.03 \mathrm{a}$ & $398.63 \mathrm{a}$ & $2.95 \mathrm{a}$ & $1.10 \mathrm{a}$ \\
\hline & $\mathrm{V}_{3}$ & $91.10 \mathrm{ab}$ & $3.33 \mathrm{c}$ & $31.71 \mathrm{~d}$ & $365.93 \mathrm{~cd}$ & $2.83 \mathrm{a}$ & $0.90 \mathrm{c}$ \\
\hline & $\mathrm{V}_{4}$ & $92.18 \mathrm{a}$ & $3.86 \mathrm{~b}$ & $35.82 \mathrm{~b}$ & $387.19 \mathrm{ab}$ & $2.80 \mathrm{a}$ & $0.99 \mathrm{~b}$ \\
\hline & $\mathrm{V}_{5}$ & $90.95 \mathrm{ab}$ & $2.90 \mathrm{~d}$ & $30.26 \mathrm{~d}$ & $354.99 \mathrm{~d}$ & $2.50 \mathrm{~b}$ & $0.80 \mathrm{~d}$ \\
\hline & $S \bar{x}$ & 0.92 & 0.10 & 0.58 & 4.11 & 0.13 & 0.03 \\
\hline & LSD & 2.66 & 0.30 & 1.67 & 11.85 & 0.27 & 0.09 \\
\hline
\end{tabular}

${ }^{*}$ Values not sharing common letters differ at $5 \%$ level of probability; ${ }^{\mathrm{a}}$ IT = Irrigation at tillering stage, ITS = Irrigation at tillering and stem elongation stage, ISB = Irrigation at stem elongation and booting stage, ITSBG = Irrigation at tillering, stem elongation, booting and grain filling stage, V1 = Faisalabad-2008, V2 = Lasani-2008, V3 = Mairaj-2008, V4 = Shafaq-2006, V5 = Chakwal-97.

$95.88 \mathrm{~cm}$ was recorded in ITS (irrigation at tillering and stem elongation stage) and lowest plant height $(88.07 \mathrm{~cm})$ was recorded in IT (irrigation at tillering stage) which was statistically at par with ISB $(89.91 \mathrm{~cm})$ and ITSBG $(90.79 \mathrm{~cm})$. Maximum plant height of $93.03 \mathrm{~cm}$ was recorded in cv. Faisalabad-2008 and it was statistically at par with Shafaq-2006. Lowest plant height $88.53 \mathrm{~cm}$ was produced by cv. Lasani-2008. These results are in line with those of [26] who reported that plant height was significantly affected by irrigation treatments.

\subsection{Leaf Area Index}

Leaf area index (LAI) is the main physiological determinant of the crop yield [3]. Figure 1 presents the effect of irrigation and cultivars on maximum LAI during the season. Application of ITSBG (irrigation at tillering, stem elongation, booting and grain filling stage) significantly produced more LAI during most of the crop season (5.50) over other irrigation levels and it was statistically at par with ISB (irrigation at stem elongation and booting stage). IT (irrigation at tillering stage) produced minimum LAI throughout the crop season (Figure 1(a)).

Cultivars had non-significant effect on LAI during most of the crop season (Figure 1(b)). Lasani-2008 gave the maximum value 5.23. The maximum LAI continued to increase up to month of February and then gradually declined towards maturity due to leaf senescence. Overall mean value of LAI for all the cultivars remained 5.09.
[4] reported that irrigation treatments significantly affected LAI.

\subsection{Total Dry Matter Accumulation}

Figure 2(a) indicated that total dry matter (TDM) accumulation was significantly affected by different irrigation levels. An increasing trend in total dry matter accumulation was observed from 40 DAS ( $22^{\text {th }}$ December) to 120 DAS (12th March) in all treatments. Application of ITSBG (irrigation at tillering, stem elongation, booting and grain filling stage) significantly increased TDM accumulation over ISB (irrigation at stem elongation and booting stage), ITS (irrigation at tillering and stem elongation stage) and IT (irrigation at tillering stage). Final TDM yield was $1146.00 \mathrm{~g} \cdot \mathrm{m}^{-2}$ in ITSBG, $1086.00 \mathrm{~g} \cdot \mathrm{m}^{-2}$ in ISB, $1005.00 \mathrm{~g} \cdot \mathrm{m}^{-2}$ in ITS and $955.50 \mathrm{~g} \cdot \mathrm{m}^{-2}$ in IT, respectively. [27] reported that total dry matter production increased as they increased the irrigation levels.

The cultivars had non-significant effect on total dry matter accumulation except on 55 DAS, 100 DAS and 120 DAS when cultivars differed significantly (Figure 2(b)). Then TDM was leveled off at final harvest. The cv. Lasani-2008 significantly increased TDM accumulation and Shafaq-2006 was statistically at par with Lasani2008 while Mairaj-2008 and Faisalabad-2008 were statistically at par. Minimum TDM was produced by $\mathrm{cv}$. Chakwal-97. In general, all cultivars showed similar trend in TDM production i.e. initially slow accumulation 


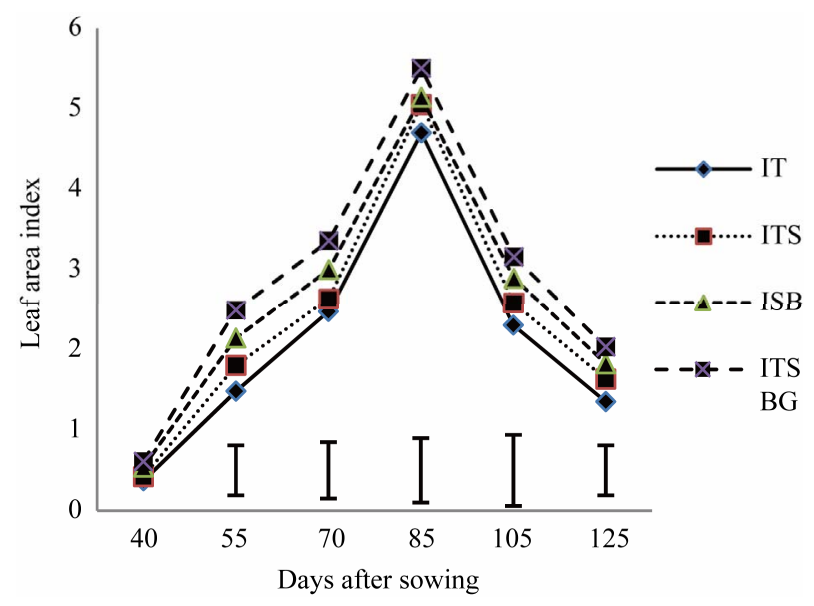

(a)

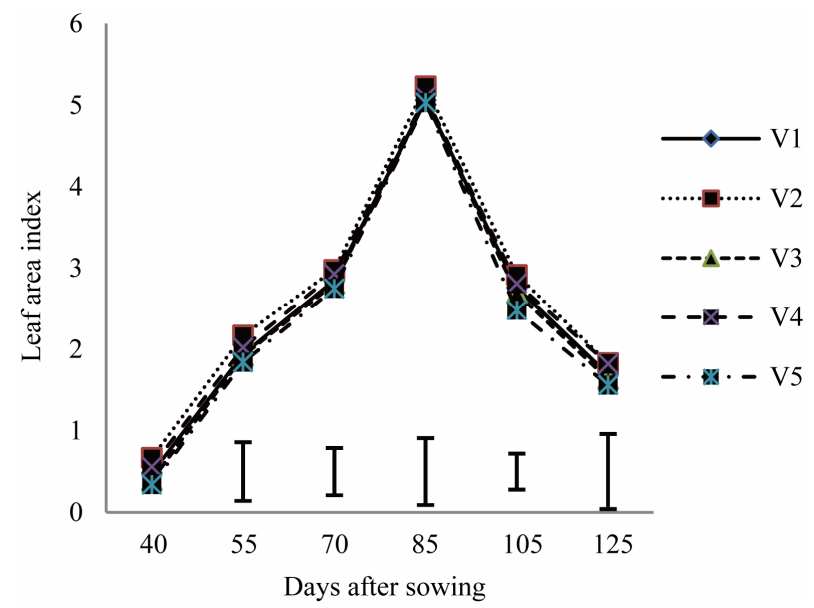

(b)

Figure 1. Changes in leaf area index with time as affected by (a) irrigation levels and (b) cultivars; bars indicate LSD at $5 \%$.

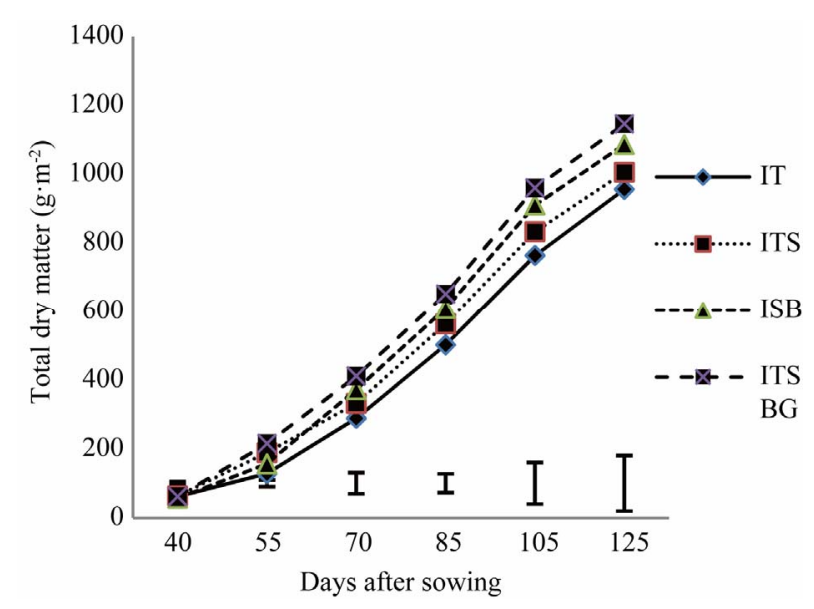

(a)

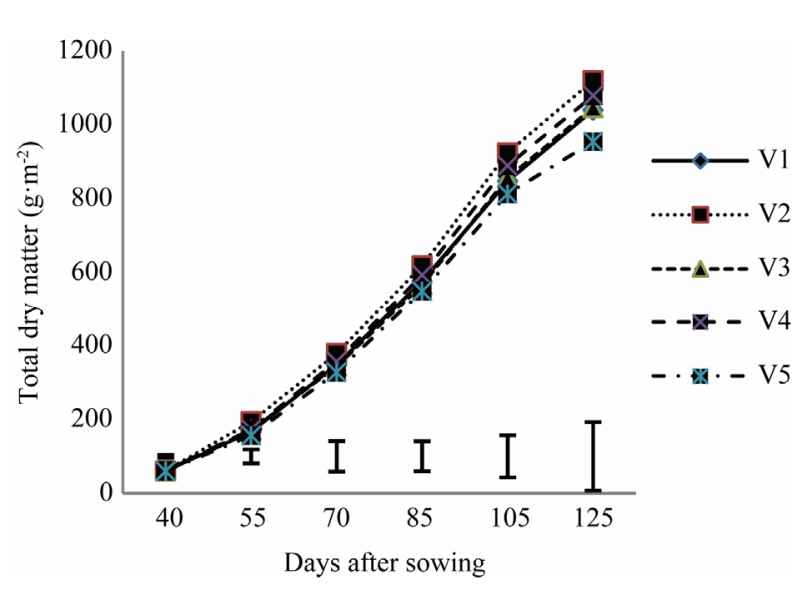

(b)

Figure 2. Changes in total dry matter accumulation with time as affected by (a) irrigation levels and (b) cultivars; bars indicate LSD at $5 \%$.

of TDM production was observed from 40 DAS (22 December) to 55 DAS (5 January) and then subsequently fast increase in accumulation of TDM up to 120 DAS (12 March) was recorded. Final TDM was maximum (1120 $\mathrm{g} \cdot \mathrm{m}^{-2}$ ) in $\mathrm{cv}$. Lasani-2008 and it was statistically at par with Shafaq-2006 $\left(1079 \mathrm{~g} \cdot \mathrm{m}^{-2}\right)$. [1] showed that the maximum biomass was obtained in Seher-2006 followed by Uqab-2000; Shafaq-2006 produced relatively less biomass $\left(1.070 \mathrm{t} \cdot \mathrm{ha}^{-1}\right)$ but its final TDM was almost similar to that of this study $\left(1.079 \mathrm{t} \cdot \mathrm{ha}^{-1}\right)$.

\subsection{Grain Yield}

Grain yield in wheat is the outcome of number of contributing and inter-related components. These are number of productive tillers per unit area, number of grains ear ${ }^{-1}$ and mean grain weight. Data in Table 3 showed significant effects of treatments among means of various irriga- tion levels and cultivars at physiological maturity. Application of ITSBG(irrigation at tillering, stem elongation, booting and grain filling stage) significantly produced more grain yield over other irrigation levels. Both ITS (irrigation at tillering and stem elongation stage) and ISB (irrigation at stem elongation and booting stage) levels were statistically at par in grain yield. The average grain yield remained $3.007 \mathrm{t} \cdot \mathrm{ha}^{-1}$ in IT, $3.533 \mathrm{t} \cdot \mathrm{ha}^{-1}$ in ITS, $3.609 \mathrm{t} \cdot \mathrm{ha}^{-1}$ in ISB and $4.234 \mathrm{t} \cdot \mathrm{ha}^{-1}$ in ITSBG. These results corroborate the findings of [4] and [11] who reported that wheat yield increased with increasing irrigation levels.

Maximum mean grain yield was $4.376 \mathrm{t} \cdot \mathrm{ha}^{-1}$ (observed in Lasani-2008) and it was statistically different from Miraj-2008, Shafaq-2006, Faisalabad-2008 and Chakwal-97 which produced grain yield of 3.326, 3.860 and 3.514, $2.903 \mathrm{t} \cdot \mathrm{ha}^{-1}$, respectively (Table 3). 


\subsection{Harvest Index (\%)}

Harvest index (HI) shows the efficiency of cultivars to transfer assimilates to economic parts of the crop. Data regarding the effect of different irrigation levels on harvest index are presented in Table 3. Application of ITSBG (irrigation at tillering, stem elongation, booting and grain filling stage) was significantly different in $\mathrm{HI}$ from IT (irrigation at tillering stage) but it was statistically at par with ITS (irrigation at tillering and stem elongation stage) and ITS was statistically at par with ISB (irrigation at stem elongation and booting stage). ITSBG gave maximum value $(36.93 \%)$ of $\mathrm{HI}$ and ITproduced lowest value $(31.36 \%)$ of HI. It is eminent from the results that water stress reduced harvest index.

Harvest index among cultivars was also statistically significant. Greater efficiency of conversion of carbohydrates into economic parts was shown by Lasani-2008 which produced 39.03\% harvest index value. Lowest efficiency of harvest index was shown by Chakwal-97 $(30.26 \%)$.

\subsection{Intercepted Radiation and Radiation Use Efficiency}

\subsubsection{Fraction of Intercepted Radiation}

Table 4 showed the effect of treatments on the fraction of intercepted radiation (Fi) during the season. The Fi showed an increasing trend from 3rd week of December to 2nd week of February in all treatments; thereafter Fi decreased until maturity. Application of ITSBG (irrigation at tillering, stem elongation, booting and grain filling stage) significantly enhanced Fi over ISB (irrigation at stem elongation and booting stage), ITS (irrigation at tillering and stem elongation stage) and IT (irrigation at tillering stage). ISB was statistically at par with ITS. However, difference in Fi between ITS and IT was significant.

Difference among cultivars was non-significant. Fraction of intercepted radiation reached its maximum value of 0.90 in Lasani-2008, 0.89 in Shafaq-2006, 0.89 in Miraj-2008, 0.89 in Faisalabad-2008 and 0.89 in Chakwal-97, respectively (Table 4).

\subsubsection{Cumulative Intercepted Radiation (PAR)}

Application of irrigation at tillering, stem elongation, booting and grain filling stage (ITSBG) significantly enhanced the cumulative photosynthetically active radiation (PAR) interception $\left(413.60 \mathrm{MJ} \cdot \mathrm{m}^{-2}\right)$ compared with ISB (391.49 $\left.\mathrm{MJ} \cdot \mathrm{m}^{-2}\right)$, ITS $\left(364.14 \mathrm{MJ} \cdot \mathrm{m}^{-2}\right)$ and IT $\left(337.66 \mathrm{MJ} \cdot \mathrm{m}^{-2}\right)$ respectively, while ISB was statistically at par with ITSBG. The cultivars showed significant effect on the amount of intercepted PAR. The mean value of cumulative intercepted radiation was $376.72 \mathrm{MJ} \cdot \mathrm{m}^{-2}$ (Table 3). Overall range of PAR remained between $354.99 \mathrm{MJ} \cdot \mathrm{m}^{-2}$ and $398.63 \mathrm{MJ} \cdot \mathrm{m}^{-2}$ which were shown by cv. Chakwal-97 and Lasani-2008, respectively.

Table 4. Effect of irrigation levels and cultivars on Fraction of intercepted radiation.

\begin{tabular}{|c|c|c|c|c|c|c|c|}
\hline & Treatments & 40 DAS & 55 DAS & 70 DAS & 85 DAS & 105 DAS & $125 \mathrm{DAS}$ \\
\hline \multirow{6}{*}{ Irrigation } & IT & 0.15 & $0.48 \mathrm{c}$ & $0.66 \mathrm{c}$ & $0.87 \mathrm{c}$ & $0.64 \mathrm{c}$ & $0.45 \mathrm{c}$ \\
\hline & ITS & 0.17 & $0.55 \mathrm{~b}$ & $0.69 \mathrm{c}$ & $0.89 \mathrm{~b}$ & $0.68 \mathrm{bc}$ & $0.51 \mathrm{bc}$ \\
\hline & ISB & 0.21 & $0.61 \mathrm{ab}$ & $0.73 \mathrm{~b}$ & $0.90 \mathrm{~b}$ & $0.72 a b$ & $0.55 \mathrm{ab}$ \\
\hline & ITSBG & 0.23 & $0.66 \mathrm{a}$ & $0.77 \mathrm{a}$ & $0.91 \mathrm{a}$ & $0.75 \mathrm{a}$ & $0.59 \mathrm{a}$ \\
\hline & $S \bar{x}$ & 0.019 & 0.019 & 0.012 & 0.005 & 0.013 & 0.02 \\
\hline & LSD & NS & 0.069 & 0.039 & 0.008 & 0.048 & 0.069 \\
\hline \multirow{7}{*}{ Cultivars } & $\mathrm{V}_{1}$ & $0.19 \mathrm{c}$ & 0.57 & 0.71 & 0.89 & 0.70 & 0.53 \\
\hline & $\mathrm{V}_{2}$ & $0.25 \mathrm{a}$ & 0.60 & 0.73 & 0.90 & 0.72 & 0.55 \\
\hline & $\mathrm{V}_{3}$ & $0.16 \mathrm{~d}$ & 0.57 & 0.71 & 0.89 & 0.69 & 0.51 \\
\hline & $\mathrm{V}_{4}$ & $0.22 \mathrm{~b}$ & 0.58 & 0.72 & 0.89 & 0.71 & 0.55 \\
\hline & $\mathrm{V}_{5}$ & $0.14 \mathrm{e}$ & 0.55 & 0.70 & 0.89 & 0.66 & 0.49 \\
\hline & $S \bar{x}$ & 0.006 & 0.015 & 0.009 & 0.002 & 0.009 & 0.015 \\
\hline & LSD & 0.008 & NS & NS & NS & 0.026 & NS \\
\hline
\end{tabular}

\footnotetext{
*Values not sharing common letters differ at 5\% level of probability; IT = Irrigation at tillering stage, ITS = Irrigation at tillering and stem elongation stage, ISB $=$ Irrigation at stem elongation and booting stage, ITSBG = Irrigation at tillering, stem elongation, booting and grain filling stage, V1 = Faisalabad-2008, V2 = Lasani-2008, V3 = Mairaj-2008, V4 = Shafaq-2006, V5 = Chakwal-97.
} 


\subsubsection{Radiation Use Efficiency (Total Dry Matter)}

Radiation use efficiency for the final dry matter (RUE ${ }_{T D M}$ ) was found to be significant statistically (Table 3). ITSBG (irrigation at tillering, stem elongation, booting and grain filling stage) significantly produced more RUE for TDM (3.07 $\left.\mathrm{g} \cdot \mathrm{MJ}^{-1}\right)$ over other irrigation levels; ISB, ITS and IT gave values of RUETDM as $2.77 \mathrm{~g} \cdot \mathrm{MJ}^{-1}$, $2.76 \mathrm{~g} \cdot \mathrm{MJ}^{-1}$ and $2.48 \mathrm{~g} \cdot \mathrm{MJ}^{-1}$ respectively. [23] reported that water stress caused significant reduction in maximum biomass production by changes in the amount of intercepted PAR. Cultivars showed its potential in terms of RUETDM ranging from $2.50 \mathrm{~g} \cdot \mathrm{MJ}^{-1}$ to $2.95 \mathrm{~g} \cdot \mathrm{MJ}^{-1}$. Cultivar Lasani-2008, Shafaq-2006 and Miraj-2008 produced more dry matter $(2.95,2.80$ and $2.83 \mathrm{~g}$, respectively) than Faisalabad-2008 (2.77 g) and Chakwal-97 $(2.50 \mathrm{~g})$ for each MJ of light [28].

\subsubsection{Radiation Use Efficiency (Grain Yield)}

Table 3 showed that increasing levels of irrigation had significant effect on RUE for grain yield ITSBG (irrigation at tillering, stem elongation, booting and grain filling stage) gave maximum RUE $1.07 \mathrm{~g} \cdot \mathrm{MJ}^{-1}$ and it was statistically at par with ISB (irrigation at stem elongation and booting stage) and thought it was statistically different from all treatments of irrigation. Lowest value $(0.82$ $\mathrm{g} \cdot \mathrm{MJ}^{-1}$ ) of RUE for Grain yield was found in IT (irrigation at tillering stage) and it was statistically at par with ITS (irrigation at tillering and stem elongation stage). The mean value of radiation use efficiency for grain remained $\left(0.94 \mathrm{~g} \cdot \mathrm{MJ}^{-1}\right)$. Cultivars significantly affected the RUE for grain. Radiation used by cv. Lasani-2008 was maximum $\left(1.07 \mathrm{~g} \cdot \mathrm{MJ}^{-1}\right)$ followed by Shafaq-2006 (0.99 $\left.\mathrm{g} \cdot \mathrm{MJ}^{-1}\right)$. Lowest value of radiation used by cultivars was found in cv. Chakwal-97 $\left(0.80 \mathrm{~g} \cdot \mathrm{MJ}^{-1}\right)$ while values of RUE shown by other varieties were cv. Faisalabad-2008 $\left(0.92 \mathrm{~g} \cdot \mathrm{MJ}^{-1}\right)$ and Miraj-2008 $\left(0.90 \mathrm{~g} \cdot \mathrm{MJ}^{-1}\right)$ [29].

Results emphasize that different treatments such as Lasani-2008 and ITSBG (irrigation at tillering, stem elongation, booting and grain filling stage) application increased yield by enhancing growth (LAI) than other treatments. This led to higher radiation interception and thus enhanced crop growth rate and increased TDM production in these treatments. [23] found the greatest reduction in RUE was also from early drought with little or no effect from mid to late drought.

In conclusion, results showed that both radiation interception and RUE were the major determinant of crop growth and yield.

\section{REFERENCES}

[1] J. Anwar, A. Ahmad, T. Khaliq, M. Mubeen and H. M. Hammad, "Optimization of Sowing Time for Promising
Wheat Genotypes in Semiarid Environment of Faisalabad," Crop Environment, Vol. 2, 2011, pp. 24-27.

[2] W. Nasim, A. Ahmad, S. A. Wajid, A. Hussain, T. Khaliq, M. Usman, H. M. Hammad, S. R. Sultana, M. Mubeen and S. Ahmad, "Simulation of Different Wheat Cultivars under Agro-Ecological Condition of Faisalabad-Pakistan," Crop Environment, Vol. 1, 2010, pp. 44-48.

[3] M. Mubeen, A. Ahmad, A. Wajid, T. Khaliq and A. Bakhsh, "Evaluating CSM-CERES-Maize Model for Irrigation Scheduling in Semi-Arid Conditions of Punjab, Pakistan," International Journal of Agriculture Biology, Vol. 15, 2013, pp. 1-10.

[4] A. Wajid, A. Hussain, M. Maqsood, A. Ahmad and M. Awais, "Influence of Sowing Date and Irrigation Levels on Growth and Grain Yield of Wheat," Pakistan Journal of Agricultural Sciences, Vol. 39, No. 1, 2002, pp. 22-24.

[5] F. Kajdi, "Effect of Irrigation on the Yield of Winter Wheat Varieties," Acta Agronomica Ovariensis, Vol. 35, 1993, pp. 221-231.

[6] E. Khehr, A. F. Matta, S. E. G. Wahba and M. M. El-Koliey, "Effect of Water Regime on Yield of Some Maize Cultivars and Water Relations," Res. Bull 47. Fac. Agric., University of Cairo Crop Res. Inst., 1996, pp. 87-98.

[7] M. A. Bajwa, M. H. Choudhry and A. Sattar, "Influence of Different Irrigation Regimes on Yield and Yield Components of Wheat," Pakistan Journal of Agricultural Research, Vol. 14, No. 4, 1993, pp. 361-365.

[8] A. Hussain, M. Maqsood, A. Ahmad, A. Wajid and Z. Ahmad, "Effect of Irrigation during Various Development Stages on Yield, Components of Yield and harvest Index of Different Wheat Cultivars," Pakistan Journal of Agricultural Sciences, Vol. 34, 1997, pp. 104-107.

[9] E. A. Waraich, R. Ahmad, A. Ali and Saifullah, "Irrigation and Nitrogen Effects on Grain Development and Yieldin Wheat (Triticum aestivum L.),"Pakistan Journal of Botany, Vol. 39, No. 5, 2007, pp. 1663-1672.

[10] E. A. Waraich, R. Ahmad, Saifullah, S. Ahmad and A. Ahmad, "Impact of Water and Nutrient Management on the Nutritional Quality of Wheat," Journal of Plant Nutrition, Vol. 33, No. 5, 2010, pp. 640-643. doi:10.1080/01904160903575881

[11] N. Sarwar, M. Maqsood, K. Mubeen, M. Shehzad, M. S. Bhullar, R. Qamar and N. Akbar, "Effect of Different Levels of Irrigation on Yield and Yield Components of Wheat Cultivars," Pakistan Journal Agricultural Sciences, Vol. 47, No. 4, 2010, pp. 371-374.

[12] A. Nazir, R. H. Qureshi, M. Sarwar and T. Mahmood, "Drought Tolerance of Wheat Genotypes," Pakistan Journal Agricultural Sciences, Vol. 24, No. 4, 1987, pp. 231-234.

[13] K. B. Bankar, S. V. Gosavi and V. K. Balsanen, "Effect of Different Irrigation Treatment on Growth and Yield of Wheat Crop Varieties," International Journal of Agriculture Sciences, Vol. 4, 2008, pp. 114-118.

[14] H. A. Jahfari, "Modeling the Growth, Radiation Use Efficiency and Yield of New Cultivars under Varying Nitro- 
gen Rates," M.Sc. Thesis, University of Agriculture Faisalabad, 2004.

[15] W. Nasim, "Modeling the Growth, Development, Radiation Use Efficiency and Yield of Different Wheat Cultivars," M.Sc. Thesis, University of Agriculture Faisalabad, 2007.

[16] H. Han, Z. Li, T. Ning, X. Zhang, Y. Shan and M. Bai, "Radiation Use Efficiency and Yield of Winter Wheat under Deficit Irrigation in North China," Plant Soil Environment, Vol. 54, No. 7,2008, pp. 313-319.

[17] A. Hussain, M. R. Chaudhry, A. Wajid, A. Ahmad, M. Rafiq, M. Ibrahim and A. R. Goheer, "Influence of Water Stress on Growth, Yield and Radiation Use Efficiency of Various Wheat Cultivars," International Journal of Agriculture and Biology, Vol. 6, No. 6, 2004, pp. 1074-1079.

[18] M. M. Acreche and G. A. Slafer, "Grain Weight, Radiation Interception and Use Efficiency as Affected by Sink-Strength in Mediterranean wheat Released from 1940 to 2005," Field Crop Research, Vol. 10, No. 2, 2009, pp. 98-105. doi:10.1016/j.fcr.2008.07.006

[19] M. Saeed, "Crop Water Requirements and Irrigation Systems," In: S. Nazir, Ed., Crop Production, National Book Foundation, Islamabad, 1994.

[20] M. Maqsood, A. Ali, Z. Aslam, M. Saeed and S. Ahmad, "Effect of Irrigation and Nitrogen Levels on Grain Yield and Quality of Wheat," International Journal of Agriculture and Biology, Vol. 4, No. 1, 2002, pp. 164-165.

[21] Government of Punjab, "Paidawarimansubagandum (Production Technology for Wheat) 2009-2010," Directorate of Agricultural Information, Punjab, 2010.

[22] J. L. Monteithand J. F. Elston, "Performance and Productivity of Foliage in the Field in the Growth and Functioning of Leaves," Cambridge University Press, Cambridge,
1983, pp. 499-518.

[23] P. D. Jamieson and M. A. Semenov, "Modeling Nitrogen Uptake and Redistribution in Wheat," Field Crop Research, Vol. 68, No. 1, 1998, pp. 21-29. doi:10.1016/S0378-4290(00)00103-9

[24] G. Szeicz, "Solar Radiation for Plant Growth," Journal of Applied Ecology, Vol. 11, 1974, pp. 617-636. doi: $10.2307 / 2402214$

[25] R. G. D. Steel, J. H. Torrie and D. A. Dickey, "Principles and Procedures of Statistics: A Biometrical Approach," 3rd Edition, McGraw Hill Book.Int, Co, New York, 1997, pp. 400-428.

[26] J. A. Thompson and D. L. Chase, "Effect of Limited Irrigation on Growth and Yield of Semi-Dwarf Wheat in Southern New South Wales," Australian Journal of EXperimental Agriculture, Vol. 32, No. 6, 1992, pp. 725730. doi:10.1071/EA9920725

[27] K. G. Mandal, K. M. Hati, A. K. Misra, K. K. Bandyopadhyay and M. Mohanty, "Irrigation and Nutrient Effects on Growth and Water-Yield Relationship of Wheat (Triticum aestivum L.) in Central India," Journal of Agronomy and Crop Science, Vol. 191, No. 6, 2005, pp. 416-425. doi:10.1111/j.1439-037X.2005.00160.x

[28] W. Nasim, A. Ahmed, M. Tariq and S. A. Wajid, "Studying the Comparative Performance of Wheat Cultivars for Growth and Grains Production," International Journal of Agronomy and Plant Production, Vol. 3, No. 9, 2012, pp. 306-312.

[29] W. Nasim, "Modeling the Growth, Development, Radiation Use Efficiency and Yield of Different Wheat Cultivars," M.Sc. Thesis, Department of Agronomy, University of Agriculture, Faisalabad, 2007, p. 130. 